\title{
The Limited Prospects for International Tax Cooperation
}

\section{Robert Kudrle}

\section{University of Minnesota}

\section{Abstract}

The recent pace of international agreement aimed to reduce tax evasion and avoidance was completely unpredicted prior to the financial crisis. The two targets are often considered to be merely different dimensions of the same problem. This paper argues that the two problems actually involve very different logics, and this holds the key to the prospects for success. The assault on tax evasion confronts a problem that is commonly recognized and admits to amelioration through the increased information sharing that is rapidly, although unevenly, advancing. Attempts to reduce corporate tax avoidance, however, confront ambiguity at every turn. National corporate tax systems differ markedly from each other in rules as well as rates, and agreement necessarily takes place in an ever more competitive international business environment in which national rate and rule setting will remain largely independent. Moreover, increased attention to the international taxation of business seems to have increased rather than dampened unilateral initiatives to advance national gain.

\section{Policy Implications}

- The US should require the collection of information on beneficial ownership of companies.

- The US should move swiftly to reduce the corporate income rate substantially while reexamining practices that others states deem abusive.

- Unilateral international business tax reforms by all states should weigh the impacts on others and involve consultation with them.

- The OECD should continue to dampen tax conflicts by applying its expertise on compromise and peer review beyond the G20.

International cooperation on tax issues falls into two broad historical periods with essentially opposite concerns. From the time of the First World War and for decades after the Second, cooperation aimed at reducing the double taxation of income that could result from overlapping revenue claims. Starting in earnest in the 1990s, the focus shifted to tax evasion and avoidance: 'double non-taxation'. That second phase continues, and activity has burgeoned in the years since the financial crisis. Both evasion and avoidance are under attack with a visibility and apparent political determination that was almost completely unpredicted prior to the crisis. Most analyses of the recent period treat evasion and avoidance together. This is a mistake because they involve very differ logics. The attack on evasion could ultimately result in a stable equilibrium outcome of greatly reduced tax cheating while the current assault on corporate tax avoidance may have accelerated unilateral initiatives and increased tax competition.

Most attention to international tax issues in political science and law devotes principal attention to revenue collection and its distribution across jurisdictions. In sharp contrast, an economic approach often focuses on wealth maximization by a unitary rational actor in which revenue gains or losses are only a component. While the single actor assumption clearly oversimplifies, this paper argues that the economic approach can illuminate the larger picture and is necessary to explore the prospects for policy development. Specifically, any forecast of cooperation on taxation requires an investigation of a state's national interest construed simply as wealth enhancement, even if that interest is substantially distorted by special interests, as it invariably is. This paper will employ that approach, paying particular attention to the largest single actor in global tax matters, the United States. Not only does the US still account for nearly a quarter of the world's product, over ten per cent of total trade, and more than a fifth of incoming and outgoing direct investment stocks, but its federal system and recently volatile politics make it the most problematic factor in global tax policy.

The paper will first outline the central argument. This is followed by a brief history of policy development over the twentieth century. The differing paths of recent international initiatives on evasion and avoidance are then explored.

The main argument here can be summarized simply: international cooperation on personal taxes will likely continue to increase, but corporate tax cooperation will remain quite limited. This prediction rests on several major differences. First, the incidence of the personal income tax in a 
closed economy is subject to some disagreement, but is widely accepted to fall mostly on the agent upon whom it is levied (Mirrlees et al, 2011). ${ }^{1}$ Second, the concept of tax evasion, although it involves penalties of varying severity across polities, ${ }^{2}$ can be defined quite clearly: a failure to pay a well-defined tax liability through the use of silence, secrecy, or deception. Third, personal taxes can be levied at widely varying rates with only minor direct impact on international personal mobility. Although the international mobility of persons in response to tax differences will grow considerably in the future (Kudrle, 2015), it remains a minor consideration for most countries now. ${ }^{3}$ All of this implies a coordination game for all but a handful of states. That latter group gains more from profits on activity involving attracted foreign funds than is lost from the impact of permissiveness on residents. But most of those states now are small, weak, and subject to coercion. Cooperation to curtail evasion through secret foreign investment is highly feasible.

The situation with the corporate income tax differs on each count. First, the incidence (who really pays?) of the corporate income tax even in a closed economy is strongly disputed as is the rationale for penalizing a particular form of business organization. The tax also distorts the economy's productive system (Mirrlees et al, 2011). Therefore, on both efficiency and equity grounds, most economists favor maximum feasible integration of business and personal taxation. Second, although corporation tax evasion cannot be ignored, the major policy concern is the scope for legal tax avoidance by large traded firms, which is inherently somewhat vague. Firms may act on several motives at once. Sometimes transactions having no economic purpose except to avoid taxation can be attacked, but avoidance is intrinsically much less clear than evasion. Third, differing effective relative tax rates among states have been shown to alter the flow of real corporate capital and overall corporate activity substantially (OECD, 2015b) as well greatly distorting the distribution of profit claims across jurisdictions. Furthermore, nearly two hundred countries in varying economic circumstances will be able to agree on only a limited set of practices, and competition among states cannot be effectively controlled if anything like the present corporate tax system remains in place.

\section{The early conventions}

Absent other considerations, states will want to collect revenue from all entities within their sphere of enforcement. So if a natural person resident in country $A$ earns income sourced in country $B, A$ will want to tax its resident and $B$ will want to tax the person's income at its source. And, without understood rules, this tension can lead to taxation levels that strangle commerce recognized as beneficial to both states.

A similar tension applies to capital: net national 'lenders' acting as unitary rational actors would favor the residence principle and net 'borrowers' the source principle. ${ }^{4}$ The acceptance of the source principle for multinational corporations (MNCs) rested on two main arguments. First, nothing could prevent source countries from taxing local activity to any extent they chose, so arguments in favor of a pure residence principle aimed at countries that were overwhelmingly hosts could not prevail. Second, the benefit principle of taxation suggests that the social framework - the legal, administrative, and physical infrastructure - for successful operation by foreign firms justifies source taxation. In contrast, portfolio (non-controlling) investment by foreigners, either through debt or equity, maps much less clearly to foreign government resource cost. Such thinking was influential in forging what became known as the '1920s compromise': direct investment was to be primarily taxed by the source ("host") state while passive income flows from non-controlling investment were to be less heavily taxed at source, with the principal tax levied by the residence ('home') country. ${ }^{5}$

These were only generally accepted notions; actual bilateral treaties and non-treaty arrangements were subject to considerable variety. Nevertheless, the presumption of source taxation of multinational profits served international business interests by making their activity more attractive to host countries. This goes a long way towards explaining why the United Nations model treaty, first presented in 1981 (United Nations Department of Economic and Social Affairs, 1981) bears a strong resemblance to that developed by the high income countries in the League of Nations and subsequently by the OECD. The models divide mainly in their language concerning the taxation of intra-firm payments (such as dividends and royalties) and the level of local activity necessary to trigger any corporate taxation at all. On these issues, the UN model is unsurprisingly more favorable to host countries.

Residence countries have adopted two major approaches to corporate taxation. Most states allow residual profits of foreign business to go untaxed at the corporate level at home, while crediting states offset foreign corporate tax payments against what would be home country tax liability. The distinction between the two approaches blurs in actual policy, however. Exemption systems typically include exceptions for foreign corporate earnings deemed to be too lightly taxed, while the principal crediting country, the United States, has allowed any remaining taxes on foreign earnings to be deferred until dividends are repatriated so long as those funds are deployed in active foreign business. Despite variety, the acceptance of the several-times revised OECD treaty of 1963 (cf. OECD, 1963, 2014) as a baseline for individual bilateral bargains, sometimes alloyed with elements of the UN instrument, avoided the expense and friction of largely redundant activity and has signaled a willingness to engage with commercial partners on terms similar to generally prevailing practice.

\section{The problem of secrecy}

Most countries - again the US is the main exception - have exempted a resident natural person's labor service income from abroad, but nearly all have attempted to tax earnings on foreign assets owned by residents (using varying 
definitions of 'resident'). In both crediting and exemption systems, personal tax evasion through the secret holding of foreign investments, often employing various business entities as vehicles, has plagued tax collection for more than a century (Avi-Yonah, 2010)

Information sharing is treated in most bilateral income tax treaties, but until recently such sharing was usually quite limited. More importantly, many of the so-called tax havens had no tax treaties, and they rejected all elements of transparency until well into this century. Their position - justified by the traditional 'revenue rule' that a state has no obligation to help another state collect taxes - had profound implications for both personal evasion and corporate avoidance. States have historically varied widely in their recognition of the concept of financial privacy, and foreign investors in high privacy states (such as Switzerland) were often merely afforded the same rights as prevailed locally. In addition, states that did not levy either personal or corporate income taxes (such as the Caribbean tax havens) claimed no reason to collect and maintain data relevant only to tax payment elsewhere.

The investment of funds in jurisdictions with little or no taxation and high levels of institutional secrecy was decried in the US Treasury's Gordon Report of 1981 (Gordon, 1981), which declared the need for international cooperation. Many of the same concerns were echoed in the OECD's Harmful Tax Competition (HTC) report of 1998 (OECD, 1998), although, as in the Gordon Report, concerns about tax evasion and avoidance were not sharply distinguished. In fact, the OECD HTC study, from which the most recent set of anti-evasion activities can be traced, anticipated an initial cooperative emphasis on the curtailment of corporate tax avoidance. HTC accepted the decision of states to impose little or no personal or corporate taxation but attacked the havens for a lack of effective exchange of information, a lack of transparency about the operation of their tax systems, and 'insubstantial' activity by foreign businesses claiming jurisdiction. Practices with similar effects within the OECD were also condemned.

The HTC project initially threatened several dozen tax havens with unspecified punitive action by OECD members. A Forum was established to draw up a list of offending jurisdictions and to implement agreed action plans with the understanding that intra-OECD measures would also be pursued. ${ }^{6}$ Following strong pressure from international business, the requirement for 'substantial' activity was effectively eviscerated by 2001 through artful changes in stated demands. It was then dropped completely at the insistence of the Bush administration, which nonetheless claimed support for measures against tax evasion. The OECD project had by then adopted a much more conciliatory approach and demanded only that the havens make a public declaration to move towards the collection and exchange of tax-relevant information upon request. Non-recalcitrant havens became Forum 'partners' in OECD efforts that created a model tax information exchange agreement (TIEA). That instrument sought to gain information that might have been obtained through tax treaties had they existed.
Existing tax treaties were also revised to make the appropriateness of such information sharing explicit.

In response to the demand for greater financial information sharing in the wake of the attacks of September 11, 2001, many tax havens declared their cooperation with the OECD and similar demands from the Financial Action Task Force, which was established by the G7 in 1989 to combat money laundering but had shifted its focus to terrorist finance. By 2007 only the tiny European semi-states of Andorra, Liechtenstein, and Monaco continued to hold out against the model TIEA.

The financial collapse of 2008 and highly publicized tax evasion schemes on both sides of the Atlantic propelled the OECD information demands to the agenda of the London G20 meeting in April, 2009, which, in turn, brought the last holdouts on board and called some other states onto the carpet.

As was the case after the Asian Financial Crisis, the G7 combined resources with mostly major developing countries in the G20 to face the global meltdown. But the G20 subsequently expanded its attention to taxes, and this changed the face of opposition to the tax havens: The non-OECD states sought control of overseas tax evasion as well as other unwanted capital outflows and more effective MNC taxation. They therefore provided a powerful legitimizing force for ignoring the complaints of the small and weak (but not typically low income) tax havens, which had continued to mount a public relations attack against the OECD's HTC as an imperialist affront.

Complete formal capitulation by the traditional tax havens would not have been predicted only a few years earlier. Nevertheless, the victory was hollow. Those seeking information needed to know what they were looking for, and the responding state had little incentive to comply beyond what would be necessary to avoid retaliation from the underserved party. The latter point underlined how disadvantageous the agreed system was for states other than the richest and most powerful. This could not be an equilibrium for the G20.

\section{Secrecy and the national interest}

The pattern of adherence to secrecy and resistance to change reveals three sets of states. The first group consists of most states that for reasons of history and general policy orientation would always lose far more by permitting financial secrecy than they could ever gain. This includes most developed countries and virtually all low income states.

The second group are net beneficiaries of secrecy or those whose governments have been persuaded that this is true. For a small state actor, the benefit of secrecy policy is the total increase in real activity drawn to the low tax (or loose regulation) jurisdiction and the associated tax revenue. The gain from this investment will be a very small fraction of the total funds involved because they come in one door and out the other with minimal local value added. But because the amount of financial activity that can be booked bears little relation to the size of the enticing jurisdiction, 
the potential benefits linked to a small gain per unit of that volume may be substantial. This can explain not only the policies of the island tax havens but also the historic reluctance of Switzerland, Austria, Belgium, Luxembourg, Liechtenstein, Andorra and Monaco to embrace both EU and HTC efforts.

Two large countries have also been conspicuously tolerant of financial secrecy: the UK and the US Both states have historically harbored huge amounts of personal foreign financial investment, much of it from low income countries in violation of those countries' domestic laws. London has long been the largest financial center in Europe, drawing funds from all over the world, some aimed at evasion. Moreover, the origin of much tax haven activity in the Caribbean, which has funneled a large share of those funds into London, fulfilled the vision of colonial administrators who saw finance as a complement to sugar and tourism in those dependent territories (Hampton and Christensen, 2002).

The US had a long history of not taxing bank interest or tracking the ownership of bank accounts (except for Canadians). In addition, the Reagan administration extended this practice to other foreign portfolio interest with the ostensible purpose of bolstering the US balance of payments. This highly profitable situation for the financial industry generated successful opposition to Bush Treasury attempts to share information as recommended by the OECD and to cooperate in the enforcement of the EU Savings Directive of 2003 (European Union, 2003).

Both the smaller reluctant states of Europe and the traditional tax havens elsewhere were clearly vulnerable to pressure from the EU and the US But little happened until the US and the UK committed to diminished secrecy. The tax bureaucracies of both had long favored such a commitment, but their political masters had remained ambivalent. It took the general stench surrounding the financial industry after 2008, intensified by some highly specific and hugely publicized instances of perfidy - such as those revealed by the stolen records of secret German investors in Liechtenstein and whistle-blowing about large numbers of US evaders encouraged by the Union Bank of Switzerland - to discredit opposition to reform (US Senate, 2008). Transparency initiatives from the Obama administration met strident opposition mainly from some libertarian elements in the Republican Party and banking industry lobbyists. The incumbent Conservative government in the UK, long under antisecrecy pressure from its major EU partners, obviously found no resistance from Labor. And, despite the economic challenges of Brexit, Theresa May has declared that anti-evasion efforts will continue and even increase (Elliott et al., 2016).

The global shift to a comprehensive and determined attack on evasion moved along two tracks. As part of macroeconomic stimulus legislation in the wake of the financial crisis, the Obama administration introduced the Foreign Account Tax Compliance Act (FATCA) of 2010 (US Congress, 2010), that levied a withholding tax of 30 per cent on all financial institutions placing investments into US markets from abroad unless those institutions reported detailed information on all accounts with American ownership.
FATCA started as hegemonic nationalist assertion rather than cooperation: the aim was to fight tax evasion by Americans. The US presented foreign institutions, not governments, with a choice: collect the demanded information or face a ruinous penalty. Major economic partners of the US strongly objected to FATCA at the outset, both as unilateralism and as a threat to national laws protecting financial privacy. But their institutions could not thrive without investment through the US financial system (Hoke, 2016). More positively, many states quickly saw that their own best interests were served by shifting the focus of cooperation from individual institutions to their national governments, which could then press for reciprocal action from the United States. Such a nationalization of compliance became the basis for the intergovernmental agreements (IGAs) that were jointly announced by the US, the UK, France, Germany, Spain, and Italy in 2012 (US Treasury, 2016) and gave great impetus to a drive for automatic information sharing that involved dozens of countries within a few years. ${ }^{7}$

US international economic bargaining is always dogged by two complications that most countries lack: a major, independent legislative role in foreign policy and the prerogatives of the several states. Both characteristics have clouded the future of FATCA. The standard language of a FATCA IGA states: 'The United States is committed to further improve transparency and enhance the exchange relationship with [FATCA Partner] by pursuing the adoption of regulations and advocating and supporting relevant legislation to achieve such equivalent levels of reciprocal automatic exchange' (US Department of the Treasury, 2014, p. 16). In other words, the US executive declares support for a high degree of reciprocity but cannot assure it. Indeed, one dissenting Republican legislator pointed out in a letter to the Treasury that parallel obligation was not part of the enabling FATCA legislation (Posey, 2013).

Congressional concurrence constrains the US executive, but so do the several states. State law governs the formation and most regulation of American business, and 'shell' companies with no purpose but obfuscation can completely conceal beneficial ownership and hence block transparency. Some American states require so little information on companies that they often serve as the weakest informational link in global webs of evasion. In principle, federal supremacy can overcome the problem, but, despite vastly differing political complexions, the states typically unite to battle federal encroachment and underfunded mandates, and they have done so strenuously on company information. Bipartisan federal legislation to require the collection and verification of beneficial firm ownership has been introduced several times without success. Nevertheless, executive commitment was signaled by 2012 Treasury regulation changes, first proposed in the Bush administration, to oblige financial institutions to collect information on interest paid to foreigners so it can be shared internationally (US Internal Revenue Service, 2012). Additionally, the Panama papers furor helped propel new Treasury regulations in 2016 that require information to be collected on beneficial ownership of new accounts in a range of financial institutions beginning in 2018. 
FATCA was only one prong of the attack. The TIEA-drafting Forum launched in 2002 was revamped and given more structure in 2009 by the OECD-initiated and G20-embraced Global Forum on Transparency and the Exchange of Information for Tax Purposes. The Global Forum immediately endorsed more effective information exchange and established a peer review system long employed by the OECD (Martens and Jakobi, 2010).

Emboldened by the apparent determination of the US and the EU to move strongly against tax evasion, the Global Forum adopted a model Convention in 2010 that contained all the core requirements of the previous model TIEA. It also covered a broader range of taxes, allowed joint tax investigations and - most important - provided the option of automatic information exchange similar to the FATCA provisions (OECD, 2012).

Just as was the case with the information by request agreements there was no explicit enforcement mechanism within the new agreed commitments. Nevertheless, the FATCA mechanism is the most obvious tool for an enforcing state: cooperate or face a stiff withholding. Incentive compatibility is notably high with the new approach, just as it was very low for the approach based on information provision upon request. Very significantly, financial institutions have a powerful interest in assuring their own government's cooperation to avoid foreign retaliation.

The OECD serves as the de facto secretariat for the G20 by developing the technical elements of automatic information exchange as well as the boilerplate for incorporation of the new approach into national law. The OECD is also orchestrating the entire project to achieve legal and administrative congruence of FATCA with both EU transparency measures and the OECD-G20 Common Reporting Standard (OECD, 2016b). The new approach holds the potential to deter tax evasion substantially. The literature on domestic taxation demonstrates that automatic earnings reporting to governments results in much higher levels of tax compliance than is achieved otherwise (US GAO, 1997).

Significant revenue stakes attach to automatic information exchange. One study estimates the annual tax loss from secrecy at $\$ 189$ billion globally (Henry, 2012). Using a very different methodology, Gabriel Zucman (2013) has estimated that eight percent of all personal wealth in held in tax havens, and three-quarters of that is not recorded. And the significance of evasion goes well beyond immediately lost revenue. Perceived evasion lowers overall tax compliance (Luttmer and Singhal, 2014).

By late 2016 more than a hundred countries had committed to the introduction of automatic information exchange within a few years. The US, however, cannot comply without overcoming the federal-state standoff. Moreover, the Republican platform of 2016 called for the abolition of FATCA as invasive and costly, and even if some version of FATCA is retained, the Trump administration would seem unlikely to push for increased US cooperation unless a politically potent case is made that it would substantially lower evasion by US taxpayers. Some have suggested foreign retaliation against a laggard US, but that might delay cooperation rather than hastening it. Bringing US policy close to what America successfully demanded from others might await a future administration.

\section{Recent initiatives on corporate income taxation}

The policy developments outlined so far were aimed mainly at personal tax evasion rather than corporate tax avoidance, but the G8's June 2013 Lough Erne declaration took on both: '(1) Tax authorities across the world should automatically share information to fight the scourge of tax evasion and (2) Countries should change rules that let companies shift their profits across borders to avoid taxes, and multinationals should report to tax authorities what tax they pay where'. (GOV.UK, 2013)

The fight against evasion had a well-defined and widely shared purpose. Although the road to automatic information sharing still faces obstacles, particularly in the US, the basic goal of such shared information has been recognized as desirable by the OECD for at least 20 years. As political opposition - benefiting polities and special interests within others - has been overcome, a stable equilibrium has come within reach. ${ }^{8}$ The situation with large firm avoidance of the corporate income tax is completely different, despite the fact that the two taxes have generated a common concern about abuse, and both are associated in the public mind with tax havens.

Riding general popular concern about international tax dodging, the OECD launched the Base Erosion and Profit Shifting (BEPS) project in 2013 declaring the main goal 'to align the right to tax with the real economic activity that generates the income' $(O E C D, 2013 b, p .19)$. At that level of generality, there was little official international disagreement.

A major facilitating practice for both base erosion and profit shifting was intra-firm transfer pricing of goods and services that were supposed to be done as if at 'arm's length' - as if the affiliates were completely independent firms - but in fact nearly always allowed great firm discretion in moving profits to low tax areas. The project first produced both an Overview (OECD, 2013a) and an Action Plan in 2013 (OECD, 2013b) and a series of final reports in October of 2015 (OECD, 2015a). The topics of the reports capture many of the main dimensions of further cooperation, and reflect rough consensus within the G20. The topics considered fell mainly into several broad clusters: inconsistent definitions of overseas entities and associated rules about intra-firm transactions; harmful government practices that allow inappropriate jurisdictional claims for various activities; the abuse of treaty provisions by allowing advantages for unintended claimants; a lack of clarity about the necessary characteristics of the 'permanent establishment' that justifies source corporate taxation in the first place; the need for more oversight of the migration of intellectual property to low tax areas not justified by value-added or risk contributions; requirements that firms clarify 'aggressive tax planning' practices to tax authorities; country by country reporting of key financial information; increased 
commitment to the timely resolution of tax disputes; and the content of a multilateral instrument that would supersede the OECD model treaty. The thirteen BEPS final reports run to over 1,900 pages, much of it suggestive, discursive, and aspirational, in sharp contrast to the far more specific language of most anti-evasion documents.

Early in 2016, ongoing BEPS deliberations under the auspices of the OECD's Committee on Fiscal Affairs concluded that the acceptance of four principles would exempt a country from special scrutiny as a likely violator of the thrust of the BEPS project. These were: tackling harmful tax practices, acting against treaty abuse, committing to country-by-country $(\mathrm{CbC})$ reporting, and improving dispute resolution. Participation in continuing BEPS activity was opened beyond the G20 to all interested countries (OECD, 2016a).

Although the BEPS project produced a massive product that achieved consensus, just below the surface lurked unresolvable tensions that might be managed but not permanently resolved. This can be seen in three broad positions that were clearly discernable before the BEPS project began.

First, the United States sought to minimize near-term change in the regime. The BEPS reports focus heavily on the US: the practices of its firms and its policies. In fact, the same Obama government that led the charge on tax evasion engaged only cautiously with the BEPS project. The domestic politics were utterly different. Except for parts of the financial industry, US business was either indifferent towards, or in support of, a clampdown on international tax evasion (US Council for International Business, 2004). In sharp contrast, US tax administrators and international business alike accepted the position that the very high US headline corporate tax rate -about 39 per cent (federal plus state) - had to be countered by rules that allowed for a much lower effective tax rate for much of US business competing abroad against more lightly taxed foreign competitors.

US politicians felt heat from influential constituent groups upset about the massive tax-deferred profits piling up in tax havens, sometimes employing legal devices that could scarcely be described with a straight face (US Congress, 2013). But leaders in both parties along with business and the tax bureaucracy saw clearly that even the most egregious of these schemes typically kept profits in the hands of Americans rather than foreign governments, and that change should be modest, at least until the US adopted more competitive corporate taxation. Completely untaxed profit, 'stateless income,' was widely decried, but most influential actors still sought to allow firms great flexibility to maximize foreign net earnings and compete successfully against rival firms governed by territorial (exemption) tax systems.

The US also wanted to maintain the interpretation of 'permanent establishment' as it has been normally recognized in America's bilateral tax treaties and interpreted under US law. This involves little attention to how nominal may be the independence of a local agent acting on behalf of a foreign firm. But other governments care a great deal. While famous US firms arranged foreign activity in ways designed to minimize permanent establishments in high corporate tax jurisdictions, host states, rich and poor, in which those firms make their sales have attempted to redefine local activity minima to increase local taxation. American MNCs take advantage of US tax code discretion that may result in little or no taxation if gains can be transferred out of the country of sales. In contrast, many prominent home countries with territorial systems employ rules that control such nontaxation.

The US accepted the BEPS principle of international sharing of certain financial information about MNC operations largely as means of enforcing its own laws. But a major US concern - shared to a varying extent by all major home countries - has been to avoid facilitating mainly, but not exclusively, low income hosts from developing rules for profit assignment that stray from the standard of 'arm's length' valuation of international transactions.

Overall, the Obama administration walked a fine line between the immediate national economic interest and global leadership in the BEPS deliberations. The national interest demanded short-run caution. Most particularly, increased effective tax rates on US MNCs could only have accelerated the already severe problem of a shift in headquarters to other countries. But the US could also suffer from obduracy about egregious practices. The claim that certain practices compensated for the absence of more sensible tax rates seemed an admission of poor governance, and it also highlighted equity issues within the business community where some purely national US firms compete against tax-advantaged US MNCs. This relates to the broader issue of tax morale. If Americans believe that their corporations are not being taxed fairly, that likely affects general tax compliance behavior, however difficult to quantify (Luttmer and Singhal, 2014).

A second identifiable position was taken by most rich states other than the US As a group they were angered by the combination of minimal claimed local activity by many major US MNCs and high estimated profits from serving their national markets. The UK Diverted Profits Tax introduced in 2015 levied a surtax on firms deemed to have avoided an appropriate level of local taxation. Australia and a number of continental EU states have moved to introduce similar taxes. More generally, the increased political attention to corporate taxation seems to have generated a major wave of unilateral initiatives in both rich and poor countries that go well beyond previous understandings of corporate tax obligation.

Finally, there are the middle and lower income states traditional tax havens excepted. Their objectives include both a lower threshold of activity for permanent establishment and a more administrable - and immediately remunerative - system for taxing MNCs thereafter. The 'arm's length' intra-firm transfer price standard challenges rich countries, but it often defeats poor ones.

BEPS final reports endorsed the maintenance of the arm's length standard and proposed no major changes in permanent establishment. BEPS's most visible innovation, the coordinated gathering of uniform information on large firm operations country by country $(\mathrm{CbC})$ involves sharing only 
among governments and not with the general public as some advocacy groups had wanted. Some leading Republican legislators have asked for statutory justification for $\mathrm{CbC}$ reporting (Hatch and Ryan, 2015), and if the Trump administration views it as a potential source of competitive disadvantage for US firms, $\mathrm{CbC}$ reporting could become another source of dispute between the US and the rest of the world.

Rhetoric about lost revenue has driven much of the political determination to tighten the international corporate tax regime, just as it has for the drive against tax evasion. Yet the initial BEPS document notes that in many cases it 'may be difficult to know which country has lost revenue'. This speaks volumes about the complexity of corporate arrangements and the great uncertainty that surrounds the incidence of the tax.

BEPS Final Report No. 11 offers some estimates of aggregate tax losses. One OECD study from a large database found global losses in 2014 to be 100 to 240 billion dollars, and there is virtual unanimity that poorer countries lose far more relative to national revenue or income than do the rich (OECD, 2015b). But such estimates rest on counterfactuals that cannot distinguish between MNC cunning and government enticement, and they rely heavily on shortfalls from what would be collected at declared tax rates. Report No. 11 concedes that a more determined effort to collect taxes at headline rates could hasten a lowering of those rates by increasing already intense international tax competition. With respect to the latter, the UK anticipates dropping its headline rate from 20 to 17 percent by 2018. In addition, the British government has declared its determination to establish the lowest rates in the G20, presumably driven by the challenges of Brexit. The 2017 Obama budget proposed a reduction in the headline federal rate, from 35 to 28 per cent (Pozen, 2015), and Donald Trump campaigned on a 15 per cent rate; both of these plans also include the elimination of deferral. These are massive changes, yet they are completely consistent with international rules. Even if not countered strategically, they would generate revenue outcomes that could be only roughly estimated. And US changes almost certainly would be countered: the US has been shown to be a Stackelberg leader ${ }^{9}$ in corporate tax rate setting (Kumar and Quinn, 2012).

The Obama administration expressed willingness to consider signing a new multilateral instrument to modify bilateral treaties so long as it includes a satisfactory recognition of the need for binding dispute arbitration, something also favored by other rich countries but traditionally resisted by lower income states. The forecast was apparently that there would be rather little substantive change in the new convention, and some questionable language could be traded off for greater constraint on departure from historical interpretations (Parillo, 2014). The Trump government might well differ. More broadly, within whatever general bounds are agreed, each home state retains the option of denying credit or exemption for what it deems inappropriate initiatives by its partners. This is clear where no treaty exists and because of its insistence on certain features, the US is party to only 68 of the more than 3,000 treaties - but it is also an option where the host country has interpreted agreements in an unacceptable way. International business taxation will continue to rest on compromise, and double taxation follows a breakdown of understanding.

The extent of feasible agreement on revised boilerplate rules for corporate taxation remains unclear. But that misses the most important point. However much compromise may be achieved on paper, the structure of the game - nearly 200 players pursuing national advantage with only minimal agreement about tax rules and essentially none about rates - cannot lead to a stable policy outcome of the kind envisioned for tax evasion. Moreover, international market forces can only intensify. This suggests ever lower corporate tax rates in the absence of radical reform.

One major departure from the current system has long been favored by many developing countries because of its apparent solution to the transfer pricing problem. The national tax base would be determined by some combination of an MNC's national sales, plant and equipment, and employment as a fraction of the firm's global totals, and then each state would then levy its own tax rate. Even if this alternative were really superior to the arm's standard on technical grounds - and careful analysis suggests skepticism (e.g., Altshuler and Grubert, 2010) - gaining agreement from scores of countries on the formula and its implementation appears completely infeasible. The states of the EU have unsuccessfully attempted to develop such a scheme for more than ten years.

Another radical solution to profit shifting lies in the 20 per cent Destination Based Cash Flow Tax, endorsed by US House Republicans in 2016, that would leave exports untaxed while taxing imports, with the overall effect only on economic rent ('excess' profits rather than all corporate income) and with collection by the country of final sales (US House of Representatives, Committee on Ways and Means, Ways and Means Committee, 2016), thus eliminating the advantages of manipulating claims about the jurisdictional sources of profit. This policy direction shares with formula apportionment the potential to throw the existing international corporate taxation system into chaos if adopted unilaterally, and it has such disruptive international distributional implications that it could not be adopted cooperatively. Moreover, it violates WTO rules that allow the remission of indirect taxes on exports such as VAT while treating remission of direct taxes on exports as a forbidden subsidy, a distinction that much US discussion treats as a technicality rather than a barrier to action (e.g. Auerbach and Holtz-Eakin, 2016). Given the Trump administration's apparent disregard for consultation or previous agreements, only domestic political forces, particularly importers who doubt economists' claims that increases in the value of the dollar would erase their seeming disadvantage, stand in the way of adoption.

\section{Conclusion}

The personal and corporate taxation elements of the international tax regime rest on very different policy logics. This 
fact may be obscured by the greatly increased attention to both in the wake of the financial crisis. The relative clarity and simplicity of an all-out attack on personal tax evasion promises eventual success. In sharp contrast, the extreme complexity of the corporate tax system and especially its inevitable competitive dimension means that success defies definition, let alone realization. Competition means that rates will almost certainly continue to fall. This will ultimately lead to a global decline in corporate tax revenue relative to national income as has already happened in many lower income countries, which as a group depend more heavily on corporate taxation than do the rich. In addition, disruptive unilateral reforms of international business taxation appear more likely than ever before.

The central role of the US in both the evasion and avoidance projects and the extent to which outcomes through the Obama administration reflected US preferences suggest a high level of remaining US hegemony in international tax matters but also great responsibility. The Trump administration may ignore the latter.

\section{Notes}

1. For the sake of simplicity the focus will be on personal income taxation but the taxation of personal wealth has many of the same characteristics.

2. In some countries, notably Switzerland, tax evasion as distinct from tax fraud, has not been treated as a felony.

3. Maximum effect could be expected within the EU. Some estimates for the departure of entrepreneurs from France in recent years in response to taxation have been large, but evidence is almost entirely anecdotal.

4. The terms are in parentheses because direct investment is ownership not lending, and hosting is not borrowing; foreign direct investment (FDI) became an increasingly large part of total capital flows over time.

5. Differing, but largely complementary, accounts of these developments are provided by Graetz and O'Hear, 1997 and Avi-Yonah, 2005.

6. Unless otherwise indicated, factual material in the rest of this section is drawn from Kudrle, 2008 and 2014.

7. A Cox proportional hazard survival analysis (justified by a TVC test) of speed of commitment to FATCA over several years shows a strongly significant positive impact of per capita GDP but not of total GDP or portfolio investment. The simplest explanation is that compliance is quite expensive and more daunting for poorer countries. Results available from the author.

8. There will likely always be international disagreement about the appropriateness of sharing with specific governments that might misuse the information.

9. In this context, such leadership means that the U.S. sets its rates knowing others will adjust to them on the followers' assumption that the U.S. will maintain its rates in the face of their adaptation. In fact, whatever the pattern of the past, the U.S. could respond with further changes.

\section{References}

Altshuler, R. and Grubert, H. (2010) 'Formula Apportionment: Is it Better than the Current System and Are There Better Alternatives?', National Tax Journal, 63 (4), pp. 1145-1184.

Auerbach, A. and Holtz-Eakin, D. (2016) The Role of Border Adjustments in International Taxation. American Action Forum, 3 November.
Available from: https://www.americanactionforum.org/research/ 14344/ [Accessed 12 December 2016].

Avi-Yonah, R. S. (2005) 'All of a Piece Throughout: The Four Ages of US International Taxation', Virginia Tax Review, 25, pp. 313-337.

Avi-Yonah, R. S. (2010) The Case Against Taxing Citizens. Law \& Economics Working Paper 12. Available from: http://repository.law.umich.edu/la w_econ_current/art12 [Accessed 14 July, 2016].

Elliott, F., Hipwell D., and Keate, G. (2016) 'May Pledges to Curb Use of Tax Havens', The Times, 26 July. Available from http://www.the times.co.uk/article/may-pledges-to-curb-use-of-tax-havens-djrbckm7c [Accessed 10 August 2016].

European Union (2003) Council Directive 2003/48/EC of 3 June 2003.

Gordon, R. A. (1981) 'Tax Havens and Their Use by United States Taxpayers: An Overview', Intertax, 9 (6), pp. 231-239.

GOV.UK. (2013) Policy Paper: G8 Lough Erne Declaration. Available from: https://www.gov.uk/government/publications/g8-lough-erne-declara tion [Accessed 4 August 2017].

Graetz, M. and O'Hear, M. (1997) 'The "Original Intent" of US International Taxation', Duke Law Journal, 46 (5), pp. 1021-1109.

Hampton, M. P. and Christensen, J. (2002) 'Offshore Pariahs? Small Island Economies, Tax Havens, and the Re-configuration of Global Finance', World Development, 30 (9), pp. 1657-1673.

Hatch, O. and Ryan, P. (2015) 'Hatch, Ryan Question Treasury's Planned Country-by-Country Reporting Regulations,' Press Release. Available from: http://waysandmeans.house.gov/hatch-ryan-question-treasurysplanned-country-by-country-reporting-regulations/ [Accessed 10 July 2016].

Henry, J. S. (2012) 'The Price of Offshore Revisited, New Estimates for Missing Global Private Wealth, Income, Inequality, and Lost Taxes', Tax Justice Network, July, p. 5. Available from: https://www.taxjustice.net/ $\mathrm{cms} /$ upload/pdf/Price_of_Offshore_Revisited_120722.pdf [Accessed 1 July 2016].

Hoke, W. (2016) 'Reporting Rule Might Deflect Criticism of US as Tax Haven', Tax Notes International, 81, pp. 421-425.

Kudrle, R. T. (2008) 'European Resistance to US Backsliding in the Attack on Tax Havens', in D. Bobrow (ed.), Hegemony Constrained: Evasion, Modification, and Resistance to American Foreign Policy. Pittsburgh, PA: University of Pittsburgh Press, pp. 184-201.

Kudrle, R. T. (2014) 'The OECD and The International Tax Regime: Persistence Pays Off', Journal of Comparative Policy Analysis, 16 (3), pp. 201-215.

Kudrle, R. T. (2015) 'Expatriation: A Last Refuge for the Wealthy?', Global Policy, 6 (4), pp. 408-417.

Kumar, M. and Quinn, D. (2012) Globalization and Corporate Taxation. Working Paper WP12/252 (October). New York: IMF.

Luttmer, E. and Singhal, M. (2014) 'Tax Morale', Journal of Economic Perspectives, 28 (4), pp. 149-168.

Martens, K. and Jakobi, A. P. (eds) (2010) Mechanisms of OECD Governance: International Incentives for National Policy Making. Oxford: Oxford University Press.

Mirrlees, J., Adam, S., Besley, T., Blundell, R., Bond, S., Chote, R. et al. (2011) Tax By Design. Oxford: Oxford University Press.

OECD (1963) Draft Convention on Double Taxation of Income and Capital. Paris: OECD Publishing.

OECD (1998) Harmful Tax Competition: An Emerging Global Issue. Paris: OECD Publishing.

OECD (2012) Automatic Exchange of Information: What It Is, How It Works, Benefits, What Remains To Be Done. Paris: OECD Publishing. Available from: oecd.org/ctp/exchange-of-tax-information/automaticexchange-of-information-report.pdf [Accessed 20 July, 2016]

OECD (2013a) Addressing Base Erosion and Profit Shifting. Paris: OECD Publishing.

OECD (2013b) Action Plan on Base Erosion and Profit Shifting. Paris: OECD Publishing.

OECD (2014) Model Tax Convention on Income and on Capital, Condensed Version. Paris: OECD Publishing. 
OECD (2015a) OECD/G20 Base Erosion and Profit Shifting Project, Information Brief - 2015 Final Report. Paris: OECD Publishing. Available from: oecd.org/ctp/beps-reports-2015-information-brief.pdf [Accessed 20 June 2016].

OECD (2015b). Measuring and Monitoring BEPS, Action 11 - 2015 Final Report. Paris: OECD Publishing.

OECD, 2016a. All Interested Countries and Jurisdictions to be Invited to Join Global Efforts Led by the OECD and G20 to Close International Tax Loopholes. Available from: http://www.oecd.org/ctp/all-interestedcountries-and-jurisdictions-to-be-invited-to-join-global-efforts-led-bythe-oecd-and-g20-to-close-international-tax-loopholes.htm [Accessed: 3 March 2016].

OECD (2016b) Automatic Exchange of Financial Account Information: Background Information Brief. Paris: OECD Publishing.

Parillo, K. (2014) 'Robert Stack - BEPS and the United States', Tax Analysts. Available from: http://www.taxhistory.org/www/features. nsf/Articles/32D2BF767EE1FF7085257DB600672C8B?OpenDocument [Accessed 10 July 2016].

Posey, B. (2013) 'Letter to Treasury Secretary Jack Lew'. Available from: http://www.repealfatca.com/downloads/Posey_letter_to_Sec._Lew_ July_1,_2013.pdf [Accessed 29 February 2016].

Pozen, R. (2015) 'US Corporate Tax Reform: Why Obama's Good Ideas Don't Add Up', Fortune. 5 February. Available from: http://fortune.c om/2015/02/05/u-s-corporate-tax-reform-why-obamas-good-ideas-dontadd-up/ [Accessed 29 February 2016].

United Nations Department of Economic and Social Affairs (1981) United Nations Model Double Taxation Convention between Developed and Developing Countries. New York: United Nations.

US Congress (2010) Hiring Incentives to Restore Employment Act (HIRE Act). Public Law 111-147: 124 STAT. 71 Title V, Subtitle A, 18 March 2010.

US Congress (2013). Hearing before the Permanent Subcommittee on Investigations. (2013) 'Offshore Profit Shifting and the US Tax Code Part 2 (Apple Inc.)'. Available from: https://www.hsgac.sena te.gov/subcommittees/investigations/hearings/offshore-profit-shiftingand-the-us-tax-code_-part-2 [Accessed 19 February 2016].

US Council for International Business (2004) Letter to Senator Ted Stevens. Available from: http://www.uscib.org/docs/Appropriations_b ill_letter.pdf [Accessed 29 February 2016].
US Department of the Treasury (2014) Model 1A IGA Reciprocal, Preexisting TIEA or DTC June 6. Available from: https://www. treasury.gov/resource-center/tax-policy/treaties/Documents/FATCAReciprocal-Model-1A-Agreement-Preexisting-TIEA-or-DTC-11-30-14.pdf [Accessed March 10 2016].

US Department of the Treasury (2016) 'Joint Statement from the United States, France, Germany, Italy, Spain and the United Kingdom Regarding an Intergovernmental Approach to Improving International Tax Compliance and Implementing FATCA', Available from: https://www.treasury.gov/press-center/pressreleases/Docume nts/020712\%20Treasury\%20IRS\%20FATCA\%20Joint\%20Statement.pdf [Accessed 29 February 2016].

US General Accounting Office (GAO) (1997) 'Taxpayer Compliance Analyzing the Nature of the Income Tax Gap' Available from: http:// www.gao.gov/assets/110/106680.pdf 1997 [Accessed 16 March 2014].

US House of Representatives, Committee on Ways and Means, Ways and Means Committee (2016), A Better Way Forward. Available from: http://abetterway.speaker.gov/_assets/pdf/ABetterWay-Tax-PolicyPape r.pdf [Accessed 15 November 2016].

US Internal Revenue Service (2012) Internal Revenue Bulletin: 2012-20, D. 9584, Guidance on Reporting Interest Paid to Nonresident Aliens. Available from: https://www.irs.gov/irb/2012-20_IRB/ar07.html [Accessed 2 March 2016].

US Senate (2008) 'Tax Haven Banks and US Tax Compliance: Staff Report' Available from https://www.hsgac.senate.gov/.../report-psistaff-report-tax-haven-banks [Accessed 10 May 2016].

Zucman, G. (2013) 'The Missing Wealth of Nations: Are Europe and the US Net Debtors or Net Creditors?', The Quarterly Journal of Economics, 128 (3), pp. 1321-1364.

\section{Author Information}

Robert T. Kudrle is Orville and Jane Freeman Professor of International Trade and Investment Policy, Hubert Humphrey School of Public Affairs and the Law School, University of Minnesota. His current research focuses on U.S. and EU competition policy and international taxation. 